\title{
Age and seasonal pattern of contagious agalactia in small ruminants in Ukraine
}

\author{
Dmytro Mykolaivych Bohach ${ }^{1}$, Borys Tymofiyovych Stegniy ${ }^{1 凶}$, \\ Mykola Volodymyrovych Bohach ${ }^{2}$, Serhii Leonidovych Pavlov ${ }^{1}$, Vitaliy Igorovych Bolotin ${ }^{1}$ \\ ${ }^{1}$ National Scientific Center, Institute of Experimental and Clinical Veterinary Medicine, 61023, Kharkiv, Ukraine \\ ${ }^{2}$ Odesa Experimental Station of the National Scientific Center, \\ Institute of Experimental and Clinical Veterinary Medicine, 65037, Odesa, Ukraine \\ boris.stegniy@gmail.com
}

Received: August 12, $2020 \quad$ Accepted: February 10, 2021

\begin{abstract}
Introduction: The aim of the study was to determine how the spread of contagious agalactia in sheep and goats in the Odesa region depended on the age of the animals and the season. Material and Methods: From January 2016 to December 2018, 1,964 ewes and 1,484 nanny goats of different age groups were studied by ELISA for antibodies to Mycoplasma agalactiae. Results: The highest incidence of contagious agalactia was registered in one-year-old animals and was 59.7-83.0\%, two-year-old ruminants showed $17.0-40.3 \%$ prevalence, in livestock at the age of 3-4 years no serological evidence of the disease was registered and in ewes and nanny goats older than 5-6 years $1.5-3.6 \%$ were infected. The most susceptible were young animals at the age of onemonth (11.6-14.5\%). The first peak of the disease was recorded in March-April (21.0-26.1\%), in the lambing period, which coincided with the beginning of lactation and the suckling period, and the second peak occurred in June-July (28.9-34.2\%), the period of maximum lactation and of manual milking of sheep and goats. Conclusion: The results of serological investigations indicate the circulation of M. agalactiae in small ruminants in the south of Ukraine. To avoid greater dissemination of the pathogen, appropriate measures should be applied and strategies for its control need to be drawn up.
\end{abstract}

Keywords: contagious agalactia, Mycoplasma agalactiae, sheep, goats, prevalence.

\section{Introduction}

Contagious agalactia of sheep and goats is widespread in countries with developed sheep farming. It is principally caused by a specific pathogen, Mycoplasma agalactiae, and characterised by lesions of the mammary glands, joints and eyes (4). According to the World Organisation for Animal Health (OIE) and as borne out by numerous research undertakings, contagious agalactia of sheep and goats is endemic in Greece (13), Italy (6), Iran (14, 24, 25), Spain $(2,11)$, Turkey (15) and Romania (20). Localised foci of the disease have also been described in Ghana and Israel (1).

The pathogen $M$. agalactiae can circulate among animals for several years, and the disease it causes has a subclinical form. If it affects more than $70 \%$ of livestock, animals manifest clinical symptoms of agalactia which are observed in the lambing period (16). Most researchers associate the seasonality of the disease with the lactation period and explain it by the higher susceptibility of lactating and newborn animals. The disease begins during lambing and ends after lactation. A chronic and asymptomatic course of contagious agalactia in goats and sheep is observed in most cases under favourable environmental conditions, namely a moderately warm and humid summer (26).

In many countries of the Mediterranean basin, M. agalactiae is a major pathogen in the development of contagious agalactia and causes significant losses in the sheep and goat dairy industry in France (23), Spain (21) and Italy (7). In Africa, and specifically in eastern Algeria, contagious agalactia also causes significant economic losses, and in one-third of the 15 million susceptible animals the disease occurs with characteristic clinical signs - mastitis, arthritis, or mastitis and keratoconjunctivitis (18).

The main aetiological agent of contagious agalactia is M. agalactiae, although other agents are known such as M. mycoides, M. capricolum, and M. putrefaciens, albeit exclusively causing agalactia in goats. In goats, 
the situation is particularly difficult, and asymptomatic carriers have been identified in chronically infected herds. Several authors indicate that contagious agalactia is registered in sheep and goat herds that are kept together and the existence of non-pathogenic mycoplasmas in the herd complicates the diagnosis of the disease $(6,27)$.

The significant spread of this disease is due to several factors: primitive methods of small ruminant breeding, the ineffectiveness of antimicrobial therapy, and the paucity of appropriate preventive measures (3). The spread of contagious agalactia and its course are also influenced by climatic and meteorological conditions, such that wider prevalence of the disease is observed in rainy years. An increase in morbidity and mortality is registered when sheep are driven to high mountain pastures, where the climate is characterised by colder, rainier and less stable weather.

Despite the rather long-term immunity that sick animals develop, on many $M$. agalactiae-positive farms contagious agalactia of sheep and goats occurs continuously. Prolonged carriage of mycoplasma ensures the preservation of the pathogen on agalactiaepositive farms in the period between enzootics, which is the main reason for the annual reinfection of nonimmune livestock (17).

Several researchers also note the importance of secondary sources of infection: soil, litter, feed, footwear and clothing of staff, and various care items contaminated with secretions of sick animals. In addition, lambs and kids can become carriers of the infection by being suckled by other ewes and nannies $(5,9)$.

Contagious agalactia of sheep and goats had not been registered in Ukraine until 2005. However, from 2003 to 2005, outbreaks of it in sheep and goats were observed in nine southern districts of the Odesa region. That is why the determination of the age and seasonal pattern of contagious agalactia of sheep and goats on the farms of the Odesa region is relevant and necessary.

The purpose of the study was to conduct epizootological monitoring of contagious agalactia of sheep and goats on the farms of the Odesa region to elucidate its dependence on the age of animals and the season.

\section{Material and Methods}

For the study on contagious agalactia of sheep and goats and the features of the epizootic situation on different farms in the south of the Odesa region, the method of epizootological research of Bakulov et al. (2) was used. Briefly, a preliminary diagnosis was estimated based on the presence of typical clinical symptoms (loss of milk production, arthritis, pneumonia, keratoconjunctivitis, and mastitis). Laboratory testing was based on serology using an M. agalactiae Screening Ab Test ELISA kit (Idexx Laboratories, Westbrook,
MN, USA) following the manufacturer's instructions. The basis for establishing a definitive diagnosis of contagious agalactia in sheep and goats is the isolation and identification of $M$. agalactiae from samples of biological material (samples of milk, ocular, vaginal, or nasal swabs, articular exudates, as well as regional lymph nodes, samples of lungs, liver, kidney, and spleen during postmortem examination), as laid down in current legislation and recommended by the OIE.

The age-specific pattern of the disease was determined in unvaccinated sheep from six flocks aged 1 year, 2 years, 3-4 years and 5-6 years on farms of the Artsyzk district in the villages of Zadunaivka and Novoivanivka, farms of the Bolgrad district in the villages of Dmytrivka and Krynychne, and others of the Tarutyn district in Nadrichne and Vynohradivka. All of the farms are in the Odesa region (Fig. 1). In total, 1,964 ewes and 1,484 nanny goats of different age groups were studied in a sampling period from January 2016 to December 2018. The blood samples were collected from sheep and goats in syringes, serum was separated and the samples were delivered to the laboratory on ice.

The incidence of contagious agalactia among young animals was determined in 475 lambs and 308 goatlings aged 1, 2, and 3 months during 2018 on a farm in the Bolgrad district and another in the Tarutyn district. The seasonal pattern of contagious agalactia was clarified on the Bolgrad sheep farm, where clinical signs characteristic of this disease had been observed among sheep and goats for the preceding 5 years.

The resulting data were processed statistically using a Microsoft Excel for Windows spreadsheet.

\section{Results}

In most cases, lactating sheep and goats in agalactiae-positive flocks show a sharp decrease in milk production and ewes have lesions mostly in one udder and can cease secreting milk completely. Affected animals also suffer reproductive disorders accompanied by abortion and stillbirth.

The intention to elucidate the pattern of correlation of age with prevalence prompted the study's conduct on sheep farms which had been continuously agalactiaepositive for the preceding 5-7 years, and the incidence rate on those farms was from $22.6 \%$ to $32.4 \%$.

Serological examination of flocks in the Artsyzk district detected that 168 ewes $(32.4 \%)$ out of 519 were infected with contagious agalactia, of which 109 $(64.9 \%)$ were in the first year of life, $52(31.0 \%)$ in the second, $1(0.6 \%)$ was between 3 and 4 years of age, and $6(3.6 \%)$ were in the 5-6-year-old age group (Table 1).

Positive results were reached for 72 (23.9\%) out of 301 Artszyk lactating goats aged two years or younger. The larger number of infected animals, 43 (59.7\%), were one year old, while $29(40.3 \%)$ of their year-older counterparts were seropositive. 


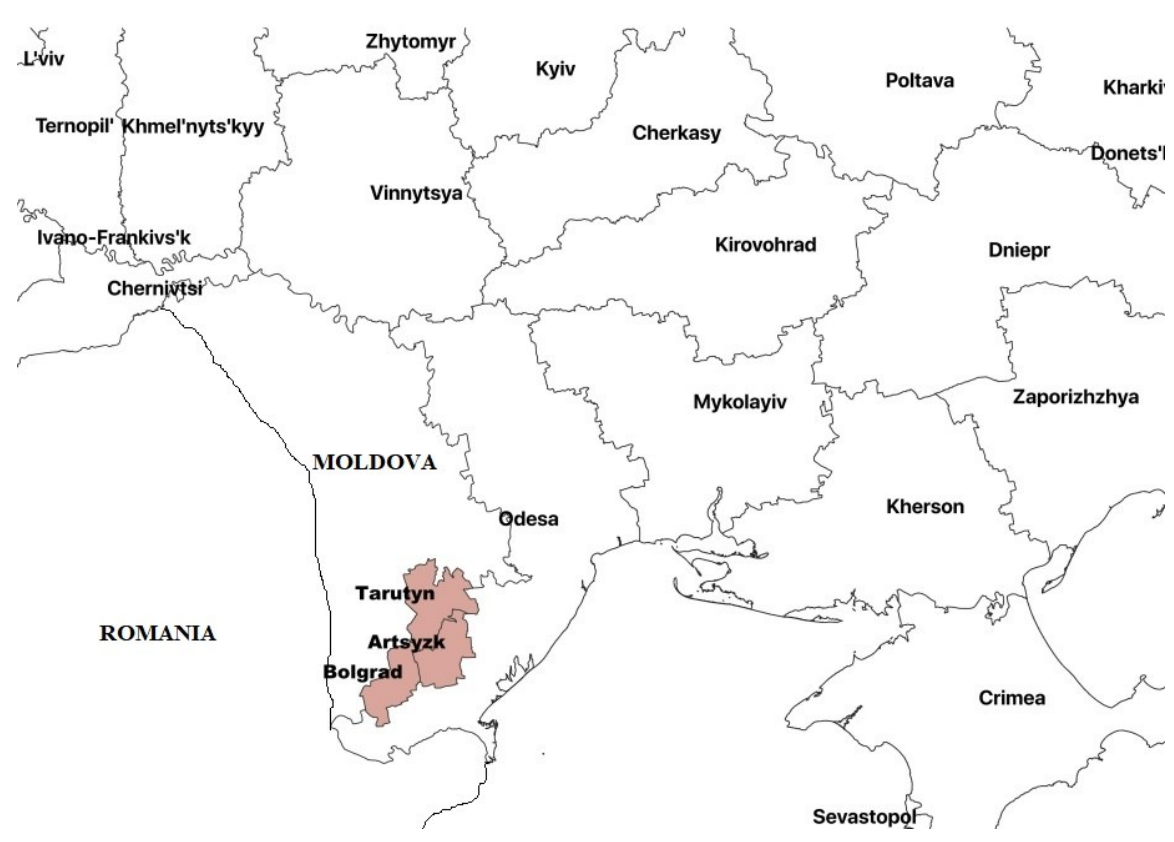

Fig. 1. Sampling locations in the Odesa region for serological testing for contagious agalactia

Table 1. Age pattern of contagious agalactia in sheep and goats on farms in the southern region of Odesa

\begin{tabular}{|c|c|c|c|c|c|c|c|c|c|c|}
\hline \multirow{3}{*}{$\begin{array}{l}\text { Small } \\
\text { ruminants }\end{array}$} & \multirow{3}{*}{$\begin{array}{c}\text { Number } \\
\text { of tested } \\
\text { animals }\end{array}$} & \multirow{3}{*}{$\begin{array}{l}\text { Number of } \\
\text { seropositive } \\
\text { animals (\%) }\end{array}$} & \multicolumn{8}{|c|}{ Incidence by age } \\
\hline & & & \multicolumn{2}{|l|}{1 year } & \multicolumn{2}{|c|}{2 years } & \multicolumn{2}{|c|}{$3-4$ years } & \multicolumn{2}{|c|}{$5-6$ years } \\
\hline & & & $\begin{array}{c}\text { Number of } \\
\text { seropositive }\end{array}$ & $\%$ & $\begin{array}{c}\text { Number of } \\
\text { seropositive }\end{array}$ & $\%$ & $\begin{array}{c}\text { Number of } \\
\text { seropositive }\end{array}$ & $\%$ & $\begin{array}{c}\text { Number of } \\
\text { seropositive }\end{array}$ & $\%$ \\
\hline & & & \multicolumn{8}{|c|}{ Artsyzk district } \\
\hline sheep & 519 & $168(32.4)$ & 109 & 64.9 & 52 & 30.9 & 1 & 0.6 & 6 & 3.6 \\
\hline \multirow[t]{2}{*}{ goats } & 301 & $72(23.9)$ & 43 & 59.7 & 29 & 40.3 & - & - & - & - \\
\hline & & & \multicolumn{8}{|c|}{ Bolgrad district } \\
\hline sheep & 586 & $146(24.9)$ & 110 & 75.3 & 32 & 21.9 & - & - & 4 & 2.8 \\
\hline \multirow[t]{2}{*}{ goats } & 470 & $106(22.6)$ & 88 & 83.0 & 18 & 17.0 & - & - & - & - \\
\hline & & & \multicolumn{8}{|c|}{ Tarutyn district } \\
\hline sheep & 859 & $210(24.4)$ & 166 & 79.0 & 44 & 21.0 & - & - & - & - \\
\hline goats & 713 & $198(27.8)$ & 139 & 70.2 & 56 & 28.3 & - & - & 3 & 1.5 \\
\hline
\end{tabular}

In the Bolgrad district where 586 sheep and 470 goats were tested, respectively $146(24.9 \%)$ and 106 $(22.6 \%)$ animals had agalactia. The incidence rate in animals in the first year of life was $75.3 \%$ in sheep and $83.0 \%$ in goats. In animals in their second year, this figure decreased to $21.9 \%$ in ewes and $17.0 \%$ in nanny goats. In 3-4-year-old animals, no clinical signs of the disease were registered, and only in $4(2.8 \%)$ ewes older than 5 years was agalactia observed, being then mastitic in form.

Investigation of a herd of small ruminants in the Tarutyn district revealed infection in $210(24.4 \%)$ out of 859 sheep and 198 (27.8\%) out of 713 goats. The incidence rate in one-year-old animals was the highest and was $79.0 \%$ among ewes and $70.2 \%$ among goats and in two-year-old animals, it was $21.0 \%$ among sheep and
$28.3 \%$ among goats. Animals aged $3-4$ years did not suffer from contagious agalactia, and only $3(1.5 \%)$ goats older than 5 years had signs of the disease.

Overall, the epizootological survey of six flocks of small ruminants in the southern districts of the Odesa region found that the highest incidence of contagious agalactia was in animals aged 1 year and ranged from 59.7 to $83.0 \%$. Among ewes and nanny goats at the age of 2 years, the incidence rate was half as high, while among lactating animals aged 3-4 years serological evidence of contagious agalactia was almost entirely absent, and only a small percentage of incidence at $1.5-3.6 \%$ was recorded among ewes and goats older than $5-6$ years.

The results of the clinical and epidemiological study of contagious agalactia among different age 
groups of sheep and goats showed that the ewes in lactating period are the most prone to the disease, as well as lambs and goats 25-30 days of age. A total of 475 lambs and 308 goatlings were examined (Table 2).

Most contagious agalactia cases were registered in animals in the age range of 25-30 days. The 475 lambs investigated included $69(14.5 \%)$ of this age with the disease and $21(4.4 \%)$ fatalities also in animals no older than a month. Thirty-six $(11.7 \%)$ of the monthlings among the 308 tested goatlings were infected and 11 (3.6\%) goatlings died before reaching month two.

Among lambs aged 2 months, the incidence rate decreased significantly and amounted to $1.3 \%$, which was six lambs. The goats of this age that had agalactia numbered $5(1.6 \%)$. The mortality of young animals was low and did not exceed $0.3 \%$. Clinical signs characteristic of contagious agalactia of sheep and goats were not registered among young animals aged 3 months.

The study of the seasonal pattern of contagious agalactia was carried out on livestock farms in the Bolgrad district of the Odesa region where sheep and goats are kept together in the same flock and grazed on the same pasture. The total number of livestock in 2016 was 425 animals, in 2017391 animals and in 2018 407, of which $114(26.8 \%), 92(23.5 \%)$ and $38(9.3 \%)$ animals were affected in respective years. This decrease in the incidence rate can be explained by the insufficient rainfall during the spring-summer period of 2018 and the drier climatic conditions generally in that year, as for the pathogen to spread humid warm weather is favourable.

During the three years of the surveillance on one sheep farm with positive status, no infected animal was registered in January (Table 3).
The first clinical signs of the disease in 2016 were registered in February, at the beginning of lambing. In 2016, 6 animals (5.3\%) were infected in February, in March the number of infected individuals increased to $26(22.8 \%)$, but in April the number decreased to 12 $(10.5 \%)$, and in May it did so again and 3 ewes (2.6\%) were affected. In June the number increased to 18 animals (15.8\%), and in July it peaked at 39 (34.2\%). In August, there were 9 infected animals $(7.9 \%)$ and in September, only $1(0.9 \%)$ animal was registered.

Similar incidence of contagious agalactia of sheep and goats was recorded in 2017. In February, 2 animals were affected $(2.2 \%)$, and in March there were already 24 (26.1\%). In April, 7 infected animals (7.6\%) were registered, but in May, only a single ruminant (1.1\%). In June, the number of infected sheep and goats grew to 21 $(22.8 \%)$ and in July the disease reached its culmination with 28 sick animals (30.4\%). At the end of summer, $7(7.6 \%)$ sheep were affected in August and 2 animals were $(2.2 \%)$ in September.

Data on agalactia incidence in sheep and goats in 2018 differed significantly from those of previous years. In February, only 1 sheep (2.6\%) with signs of agalactia was noted, in March 6 (15.8\%), but in April there was a rise to $8(21.1 \%)$, while in May there were no ruminants with the symptoms of the disease. In June, with the beginning of manual milking, 11 animals were affected $(28.9 \%)$, in July there were $7(18.4 \%)$, in August came a further fall to $4(10.5 \%)$ and in September there was a solitary case $(2.6 \%)$.

After the end of the lactation period and after the culling of young animals with positive status for this disease, no sick animals were diagnosed in October, November, or December (Fig. 2)

Table 2. Incidence of contagious agalactia among lambs and goatlings

\begin{tabular}{|c|c|c|c|c|c|c|c|c|c|c|c|c|c|}
\hline \multirow{3}{*}{$\begin{array}{l}\text { Small } \\
\text { ruminant }\end{array}$} & \multirow{3}{*}{$\begin{array}{c}\text { Number of } \\
\text { tested } \\
\text { animals }\end{array}$} & \multicolumn{12}{|c|}{ Incidence by age } \\
\hline & & \multicolumn{4}{|c|}{1 month } & \multicolumn{4}{|c|}{2 months } & \multicolumn{4}{|c|}{3 months } \\
\hline & & Affected & $\%$ & Fatalities & $\%$ & Affected & $\%$ & Fatalities & $\%$ & Affected & $\%$ & Fatalities & $\%$ \\
\hline lambs & 475 & 69 & 14.5 & 21 & 4.4 & 6 & 1.3 & 0 & - & 0 & - & 0 & - \\
\hline goatlings & 308 & 36 & 11.6 & 11 & 3.6 & 5 & 1.6 & 1 & 0.3 & 0 & - & 0 & - \\
\hline
\end{tabular}

Table 3. Seasonal pattern of contagious agalactia among sheep

\begin{tabular}{|c|c|c|c|c|c|c|}
\hline \multirow{2}{*}{ Months } & \multicolumn{2}{|c|}{2016} & \multicolumn{2}{|l|}{2017} & \multicolumn{2}{|l|}{2018} \\
\hline & Infected animals & $\%$ & Infected animals & $\%$ & Infected animals & $\%$ \\
\hline January & - & - & - & - & - & - \\
\hline February & 6 & 5.3 & 2 & 2.2 & 1 & 2.6 \\
\hline March & 26 & 22.8 & 24 & 26.1 & 6 & 15.8 \\
\hline April & 12 & 10.5 & 7 & 7.6 & 8 & 21.0 \\
\hline May & 3 & 2.6 & 1 & 1.1 & - & - \\
\hline June & 18 & 15.8 & 21 & 22.8 & 11 & 28.9 \\
\hline July & 39 & 34.2 & 28 & 30.4 & 7 & 18.4 \\
\hline August & 9 & 7.9 & 7 & 7.6 & 4 & 10.5 \\
\hline September & 1 & 0.9 & 2 & 2.2 & 1 & 2.6 \\
\hline October & - & - & - & - & - & - \\
\hline November & - & - & - & - & - & - \\
\hline December & - & - & - & - & - & - \\
\hline
\end{tabular}




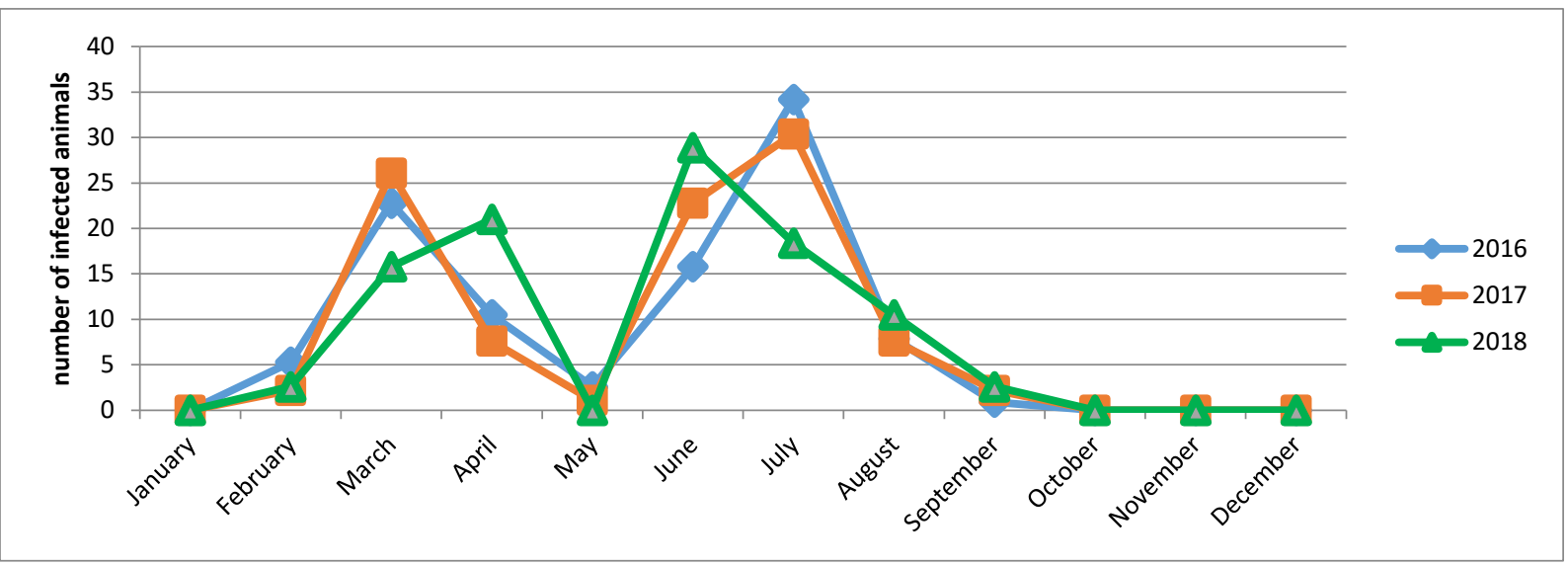

Fig. 2. Dynamics of incidence of contagious agalactia among sheep on the farms of the southern region of Odesa, Ukraine

Thus, contagious agalactia of sheep and goats is characterised by seasonality. The first peak of the disease occurs in the spring, during the lambing season, which coincides with the beginning of lactation (the suckling period). The second peak is registered in the summer, in the period of maximum lactation in animals when manual milking of sheep and goats takes place.

\section{Discussion}

Mycoplasma agalactiae remains an important pathogen, causing mastitis in lactating animals which leads to significant economic losses all over the world $(8,10)$. Besides the drop in milk production, contagious agalactia of sheep and goats is also characterised by keratoconjunctivitis, arthritis, and pneumonia followed by increasing morbidity and mortality. A serious threat to animal welfare can be observed not only in the acute phase of the disease, but also during its chronic form (19).

Currently, vaccination of sheep and goats against contagious agalactia is not provided in Ukraine and the detected antibodies in this survey reflect a natural response to infection. In our study, serological investigations on six farms in three districts of the Odesa region showed $26.7 \%$ and $25.3 \%$ seropositive animals among sheep and goat flocks, respectively. The transmission which resulted in these rates may be due to direct contact with infected animals or contaminated milking equipment on the observed farms. Suckling lambs and goats can be easily infected through colostrum and milk. Contreras et al. (8) observed several outbreaks of contagious agalactia among sheep and reported that among the ewes in lactating period from 30 to $50 \%$ of animals were sick. Lambs of $2-3$ weeks of age that were suckled by sick ewes usually died 10-15 days after the onset of symptoms in their mothers.

Analysing the contagious agalactia incidence among sheep and goats by age and sex, it was found that in ewes it is $20.1 \%$, in rams it is $0.9 \%$, in lambs $9.9 \%$, in nanny goats $48.6 \%$, in male goats $0.5 \%$ and in goatlings $20 \%$. Both sexes of young animal are affected in equal proportions (10). According to authors from Nigeria, acute and subacute courses of contagious agalactia were observed in goats 1-3 years of age, mainly in mastitic form (12).

Contagious agalactia is considered a neglected disease of small ruminants in Ukraine, the neglect signalled by poor diagnostics, failure to mitigate fast pathogen transmission from flock to flock, and insufficient sheep and goat farm managing practices. Moreover, there are inappropriate biosecurity measures and there is no vaccination program even where particularly needed in the endemic Odesa region. The disease is characterised by seasonality, striking most heavily at the end of the lambing and kidding seasons spanning winter and spring and coinciding with the beginning of lactation and in summer when the maximum number of livestock are in lactation (22). As problematic districts have a border with the Republic of Moldova, the pathogen can migrate through the adjacent territories and cross from one country to the other. Sheep and goat farms in northeastern Romania near the Republic of Moldova have also reported infectious agalactia cases for many years (20).

In conclusion, to eradicate $M$. agalactiae infection, more efficient measures for suppression and control are required. Our further objectives are to characterise isolated pathogens in greater detail using molecular methods and to examine samples from more regions of Ukraine.

Conflict of Interests Statement: The authors declare that there is no conflict of interests regarding the publication of this article.

Financial Disclosure Statement: The study was supported by the National Academy of Agrarian Sciences of Ukraine.

Animal Rights Statement: The experiments were conducted in accordance with the local Ethical Committee laws and regulations. 


\section{References}

1. Al-Momani W., Nicholas R.A., Abo-Shehada M.N.: Risk factors associated with Mycoplasma agalactiae infection of small ruminants in northern Jordan. Prev Vet Med 2008, 83, 1-10, doi: 10.1016/ j.prevetmed.2007.08.003.

2. Bakulov I.A., Vedernikov V.A., Semenikhin A.L.: Эпизоотология с микробиологией (Epizootology with microbiology - in Russian), $2^{\text {nd }}$ edition, edited by I.A. Bakulov, Kolos, Moscow, 2000, pp. 480.

3. Belaid B., Le Goff C., Lefèvre P.C.: Enquête épidémiologique et sérodiagnostic de l'agalaxie contagieuse des petits ruminants de l'Est algérien (Epidemiological and serodiagnostic survey of contagious agalactia of sheep and goats in eastern Algeria - in French). Rev Elev Med Vet Pays Trop 1990, 43, 37-41, doi: 10.19182/remvt.8892.

4. Bergonier D., Berthelot X., Poumarat F.: Contagious agalactia of small ruminants: current knowledge concerning epidemiology, diagnosis and control. Rev Sci Tech 1997, 16, 848-873, doi: 10.20506/rst.16.3.1062.

5. Bergonier D., Solsona M., de Simone F., Russo P., Poumarat F.: Study of Mycoplasma agalactiae antigenic variability using monoclonal antibodies. In: Mycoplasmas of Ruminants: Pathogenicity, Diagnostics, Epidemiology and Molecular Genetics, edited by J. Frey, K. Sarris, Publications Office of the EU, Luxembourg, 1996, pp 52-54.

6. Castro-Alonso A., Rodríguez F., de la Fé C., Espinosa de los Monteros A., Poveda J.B., Andrada M., Herráez P.: Correlating the immune response with the clinical-pathological course of persistent mastitis experimentally induced by Mycoplasma agalactiae in dairy goats. Res Vet Sci 2009, 86, 274-280, doi: 10.1016/j.rvsc.2008.06.004.

7. Cillara G., Manca M.G., Longheu C., Tola S.: Discrimination between Mycoplasma mycoides subsp. capri and Mycoplasma capricolum subsp. capricolum using PCR-RFLP and PCR. Vet J 2015, 205, 421-423, doi: 10.1016/j.tvj1.2015.05.013, doi.org/ 10.1016/j.tvj1.2015.05.013.

8. Contreras A., Siera D., Sánchez A.: Mastitis in small ruminants. Small Rumin Res 2007, 68, 145-153, doi.org/10.1016/ j.smallrumres.2006.09.011.

9. Corrales J.C., Sánchez A., Luengo C., Poveda J.B., Contreras A.: Effect of clinical contagious agalactia on the bulk tank milk somatic cell count in Mursiano-Granadina goat herds. J Dairy Sci 2004, 87, 3165-3171, doi.org/10.3168/jds.S0022-0302(04)73451-7.

10. Damdinsurén C.: Mycoplasma infections in farm animals: specific prevention of infectious (contagious) agalactia in the sheep and goat (in Russian). Arch Exp Veterinarmed 1989, 43, 769-772.

11. De Garnica M.L., Rosales R.S., Gonzalo C., Santos J.A., Nicholas R.A.: Isolation, molecular characterization and antimicrobial susceptibilities of isolates of Mycoplasma agalactiae from bulk tank milk in an endemic area of Spain. J Appl Microbiol 2013, 114, 1575-1581, doi:101111/jam.12176.

12. Egwu G.O., Ameh J.A., Aliyu M.M., Mohammed F.D.: Caprine mycoplasmal mastitis in Nigeria. Small Rumin Res 2001, 39, 87-91, doi: 10.1016/s0921-4488(00)00156-5.

13. Filioussis G., Ioannou I., Petridou E., Avraam M., Giadinis N.D., Kritas S.K.: Isolation and analysis of tetracycline-resistant Mycoplasma agalactiae strains from an infected goat herd in Cyprus - short communication. Acta Vet Hung 2013, 61, 291-296, doi: 10.1556/AVet.2013.018.
14. Hajizadeh A., Ghaderi R., Ayling R.D.: Species of Mycoplasma causing contagious agalactia in small ruminants in Northwest Iran. Vet Ital 2018, 54, 205-210, doi: 10.12834/VetIt.831.4072.2.

15. Hanedan B., Kirbas A., Kandemir F., Aktaş M., Yildiz A.: Evaluation of arginase activity, nitric oxide and oxidative stress status in sheep with contagious agalactia. Acta Vet Hung 2017, 65, 394-401, doi: 10.1556/004.2017.037.

16. Jafarizadeh A., Pourbakhsh S.A., Tadayon K., Jamshidian M.: Detection and Isolation of Mycoplasma capricolum Subspecies capricolum from East Azerbaijan Sheep Flocks. Arch Razi Inst 2017, 72, 243-248, doi: 10.22092/ari.2017.113303.

17. Jasper D.E., Dellinger J.D., Hakanson H.D.: Effectiveness of certain teat dips and sanitizers in vitro and on teat skin against Mycoplasma agalactiae subsp. bovis. Cornell Vet 1976, 66, 164-171.

18. Loueiro D., Moura-Costa L.F., Jordão R.S., Menezes N.C., Macedo E.S, Guimarães T.S., Meyer R., Portela R.W.: Seroprevalence of antibodies against bacterial pathogens in sheep from Equatorial Guinea. Rev Sci Tech 2017, 36, 965-970, doi: 10.20506/rst.36.3.2728.

19. Manso-Silván L., Perrier X., Thiaucourt F.: Phylogeny of the Mycoplasma mycoides cluster based on analysis of five conserved protein-coding sequences and possible implications for the taxonomy of the group. Int J Syst Evol Microbiol 2007, 57, 2247-2258, doi:10.1099/ijs.0.64918-0.

20. Mihai I., Velescu E., Tanase O.: Epidemiological Observations on Infectious Pathology of Goats in the Northeast Area of Romania, "Agriculture for Life, Life for Agriculture" Conference Proceedings 2018, 1, 449-454, doi: 10.2478/alife-2018-0069.

21. Paterna A., Sánchez A., Gómez-Martín A., Corrales J.C., de la Fé C., Contreras A., Amores J.: Short communication: In vitro antimicrobial susceptibility of Mycoplasma agalactiae strains isolated from dairy goats. J Dairy Sci 2013, 96, 7073-7076, doi: $10.3168 /$ jds.2012-6492.

22. Peixoto R.M., Amanso E.S., Cavalcante M.B., Azevedo S.S., Pinheiro Junior J.W.: Fatores de risco para mastite infecciosa em cabras leiteiras criadas no estado da Bahia. Arq Inst Biol 2012, 79 , 101-105, doi: 10.1590/S1808-16572012000100015.

23. Poumarat F., Gautier-Bouchardon A.V., Bergonier D., Gay E., Tardy F.: Diversity and variation in antimicrobial susceptibility patterns over time in Mycoplasma agalactiae isolates collected from sheep and goats in France. J Appl Microbiol 2016, 120, 1208-1218, doi: 10.1111/jam.13083.

24. Rahimabadi E., Asadpour Y., Pourbakhsh S.A., Sayehban P.: Isolation and Identification of Mycoplasma agalactiae by Culture and Polymerase Chain Reaction Methods in the Sheep Herds in Guilan Province, Iran. Arch Razi Inst 2017, 72, 219-223, doi: 10.22092/ari.2017.113298

25. Shamsaddini B.M., Pourbakhsh S.A., Ezatkhah M., Ashtari A.: Detection of Mycoplasma agalactiae in Small Ruminants of Southeast Iran. Arch Razi Inst 2017, 72, 237-242, doi: 10.22092/ari.2017.113302.

26. Tola S., Rizzu P., Leori G.: A species-specific DNA probe for the detection of Mycoplasma agalactiae. Vet Microbiol 1994, 41, 355-361, doi: 10.1016/0378-1135(94)90031-0.

27. Verbisck G., Gonzalez-Candela M., Cubero M.J., León-Vizcaíno L., Serrano E., Perales A.: Mycoplasma agalactiae in Iberian ibex (Capra pyrenaica) in Spain. Vet Rec 2010, 167, 425-426, doi: $10.1136 /$ vr.c4908 